\title{
A HISTOLOGICAL AND HISTOCHEMICAL EXAMINATION OF IMPLANTATION AND EARLY PLACENTOME FORMATION IN SHEEP
}

\author{
D. P. BOSHIER \\ Department of Physiology and Anatomy, Massey University, \\ Palmerston North, New Zealand
}

(Received 7th December 1967, accepted 5th August 1968)

\begin{abstract}
Summary. Embryo attachment and implantation in the ewe have been examined with a view to (a) elucidating the interrelationships of the trophoblast and the uterine epithelium, and (b) defining accurately the time relationships of the various phenomena. Embryonic attachment occurred during the 15th day of pregnancy and cytological changes within the uterine caruncular epithelium that appeared on the following day and were completed within a week, resulted in the formation of plaques of multinucleate symplasm and the death of some maternal epithelial cells.

High levels of acid phosphatase activity, considered to demonstrate the release of lysosomal hydrolases, were associated with the modification of the maternal epithelium and with the later trophoblastic invasion of the uterine stroma. Alkaline phosphatase activity present in the apical cell membranes of the opposing trophoblast and uterine epithelium is considered to be associated with carbohydrate metabolism and the production of trophoblastic fibrinoid.

No evidence was obtained to support proposals that trophoblastic binucleate giant cells have a major role in modifying the uterine epithelium through their phagocytic activity or as a source of the cryptal epithelium. The cryptal epithelium during the first 6 weeks of pregnancy appears to be derived from the symplasmic plaques of maternal epithelium.
\end{abstract}

\section{INTRODUCTION}

Both the manner in which implantation occurs in the ewe and the definitive structure of the individual placentomes have been the subject of much discussion since the early descriptions of Assheton (1906) and Jenkinson (1906). These discussions have centred on the part played by the trophoblastic binucleate cells in the degradation of the uterine epithelium and in the formation of the symplasm lining the maternal sides of the caruncular crypts (see particularly Amoroso, 1952; Björkman, 1965; Davies \& Wimsatt, 1966).

The removal of the ovine uterine epithelium before its replacement by the symplasm was described by Assheton (1906) and Amoroso (1951, 1952) as being due, principally, to the phagocytic activity of the trophoblastic binucleate 
cells. In the primates, on the other hand, the trophoblast has been considered to destroy the underlying endometrial tissues by proteolytic and cytolytic substances (Wislocki \& Bennett, 1943; but compare Fawcett, Wislocki \& Waldo, 1947).

It was found in an investigation of ovine prenatal mortality at 18 days of gestation that, in the uteri examined, the caruncular epithelium had been shed with the embryonic membranes (Boshier, 1968). It appeared that the integrity of the uterine epithelium had been disturbed in a fashion greater, and probably earlier, than that expected to result from the levels of trophoblastic binucleate cell phagocytosis described by Assheton (1906) and Amoroso (1952). It was therefore considered advisable to re-investigate embryonic implantation in the ewe, using histological and histochemical techniques, with a view to elucidating the interrelationships of the trophoblast and the uterine epithelium, and to defining more accurately the time relationships of the various phenomena.

\section{MATERIALS AND METHODS}

New Zealand Romney ewes of mixed ages, running on normal pasture, were mated with rams of the same breed which had been fitted with a 'sire-sine' harness (Radford, Watson \& Wood, 1960). The ewes were checked for service marks each morning and the first morning of oestrus recorded as Day 0. Ewes required for control histochemical studies were mated with a vasectomized ram similarly harnessed. Embryonic and maternal tissues were then collected at specific times after mating so as to give a complete series from 14 to 30 days of gestation, and at frequent intervals thereafter.

Tissues for histological examination were obtained from uteri fixed by perfusion with buffered formalin (Lillie, 1954), normally through the posterior dorsal aorta after laparotomy of ewes anaesthetized with pentobarbitone sodium (Nembutal, Abbott). Occasionally the fixative was perfused through both arteries of uteri taken immediately after the death of exsanguinated ewes. The uteri were then stored in buffered formalin until prepared for histological examination. Large pieces of the uterine body, or whole segments of smaller portions of the uterine cornua were embedded in paraffin wax, and then trimmed so that individual caruncles could be sectioned. As a result of these techniques, there was negligible disturbance of the close association between the embryonic membranes and the uterine epithelium. Histological sections, cut at 5 to $6 \mu$, were stained with either haematoxylin and eosin, van Gieson's stain, or by using the periodic acid-Schiff (PAS) technique. For the latter, diastase-digested controls were prepared. Tissues from forty pregnant and four non-pregnant ewes were used in the histological studies.

Fresh tissues for histochemical studies, taken immediately from exsanguinated ewes, were placed in the cold $\left(4^{\circ} \mathrm{C}\right)$ fixative as required. All frozen sections were cut at 10 to $20 \mu$ in a microtome cryostat. Histochemical demonstrations of alkaline phosphatase activity used a simultaneous coupling azo-dye technique in which sections were incubated for $30 \mathrm{~min}$ at 1 to $4^{\circ} \mathrm{C}$ in a mixture containing half the substrate recommended by Gomori (1952). The hexazonium pararosanilin coupler technique of Barka \& Anderson (1962) was used for the 
localization of acid phosphatase activity. Control solutions lacking the substrate were prepared and used for representative sections in the demonstration of both phosphatases. Tissues for histochemical studies were taken from twenty-nine pregnant and eight non-pregnant ewes.

\section{RESULTS}

\section{Early association between the embryonic membranes and uterine epithelium}

By the 15th day of pregnancy, the blastocyst developing within a uterine horn had grown sufficiently to come into close contact with the entire uterine epithelium of the horn in which it had developed. Although the association at this time was loose and the embryonic membranes were easily dislodged in fresh material, there were already discrete areas of close attachment of the trophoblast to the caruncular epithelium (Pl. 1, Figs. 2, 3; cf. Fig. 1).

During the early stages of the 3rd week of gestation, alkaline phosphatase activity was present in both the luminal surface of the uterine epithelial cells and the sub-epithelial capillaries within the endometrial stroma (Pl. 2, Figs. $5,8)$. Increasingly strong acid phosphatase activity was demonstrable within fine granules in the apical regions of the uterine epithelial cells of pregnant females from the 14th to the 16th day of pregnancy. By the 16th day, this superficial response was accompanied by a low level of enzyme activity in the sub-epithelial stromal cells (Pl. 2, Figs. 6, 9). Neither the strong apical activity nor the sub-epithelial response could be demonstrated in the non-pregnant ewe 14 or 16 days after mating (Pl. 2, Fig. 7). A positive PAS reaction, resistant to diastase, was obvious in a narrow amorphous layer between the trophoblast and the caruncular epithelium. This reaction was strongest where the embryonic and maternal tissues came into closest contact. A similar, but narrower, PAS-positive line was present between the uterine epithelium and stroma.

\section{Changes in the uterine epithelium}

Modification of the cytological character of the caruncular epithelium was first apparent on the 16th day of pregnancy. Although a general plan of breakdown of cellularity with associated symplasm formation was followed during the next week, the epithelium of each caruncle did not go through the same changes at the same times.

Initially, the trophoblast was closely attached to the caruncular columnar epithelium (Pl. 1, Fig. 4). From the 16th day until half-way through the 4th week of pregnancy, the caruncular epithelium underwent a series of changes. A reduction in the number of epithelial cells, which resulted from cell death within the maternal epithelium, was usually associated with nuclear vacuolation, swelling and disintegration (PI. 2, Fig. 10; cf. Pl. 1, Fig. 4). In some sections, patches of necrotic cells were visible between the plaques of multinucleate symplasm (PI. 2, Fig. 11). Transitional zones occurred between areas of normal and attenuated epithelium. In the latter, there were few nuclei lying parallel with the basement membrane in a narrow layer of cytoplasm. During this time, the sub-epithelial stroma became oedematous and contained increased numbers of eosinophils. 
Although, during the latter part of the 3rd week of pregnancy, acid phosphatase activity was still present in the caruncular epithelial area, it declined during the 4th week and was then chiefly demonstrable in the stromal tissue beneath the degenerating maternal epithelium. Activity within the intercaruncular epithelium was maintained however, and this epithelium underwent the cellular changes characteristic of the implantation process during the 5 th and 6th weeks of gestation, i.e. some 2 weeks after the caruncular epithelium. Alkaline phosphatase activity was found at the junction of the trophoblast and the maternal epithelium and was particularly apparent during the 4th week on the surface of the trophoblastic cells adjacent to the caruncle (Pl. 3, Fig. 13). The strong reactivity characteristic of the sub-epithelial capillaries of the maternal stroma was maintained throughout the 3rd and 4th weeks of gestation.

\section{The trophoblastic binucleate cells}

Identified by their strongly PAS-positive, diastase-resistant properties, the trophoblastic binucleate cells appeared first during the 16th day of gestation and increased in number thereafter (Table 1 and Pl. 2, Figs. 10, 11). These cells were most numerous in the distal trophoblast (apposed to the maternal epithelium) and occasionally were located between the trophoblast and the uterine epithelium. By the 19th day of gestation, the proportions of binucleate cells outside the trophoblast had increased slightly (17 days- $-2.5 \%$ of all binucleate cells; 19 days $-3.7 \%$ of all binucleate cells) and, as well as an increased number between the trophoblast and the uterine epithelium, there were also binucleate cells within the uterine epithelium or close to its basement membrane. The data in Table 1 show further that at 16 days of gestation, when the cytological changes in the uterine epithelium were first apparent, in each microscopical section of an entire horn there were on average about eight binucleate cells close to the uterine epithelium but still within the trophoblast, and only one cell in close contact with the maternal tissues. By the 19th day of gestation, when considerable modification of the maternal epithelium was present (Pl. 2, Fig. 11), the numbers of binucleate cells located distally within the trophoblast in each section had increased to about fifty-five, but still only three or four were in intimate contact with cells of the uterine epithelium. In one section at 19 days, two binucleate cells were observed beneath the epithelial basement membrane, just within the endometrial stroma. Binucleate cells with small pycnotic nuclei were seen between the embryonic and maternal tissues within the uterine epithelium, but not in the trophoblast. There was no evidence of any mitotic or aggregative activity and little evidence of phagocytic activity in the binucleate cells.

\section{Early stages of placentome formation}

The first signs of the interdigitation of embryonic and maternal tissues appeared early in the 4th week of gestation. A series of ridges and grooves in which there was a close association between the chorion and the endometrium developed on the caruncular surface (Pl. 3, Fig. 16). These endometrial grooves, which deepened and branched as development proceeded, were lined in some 


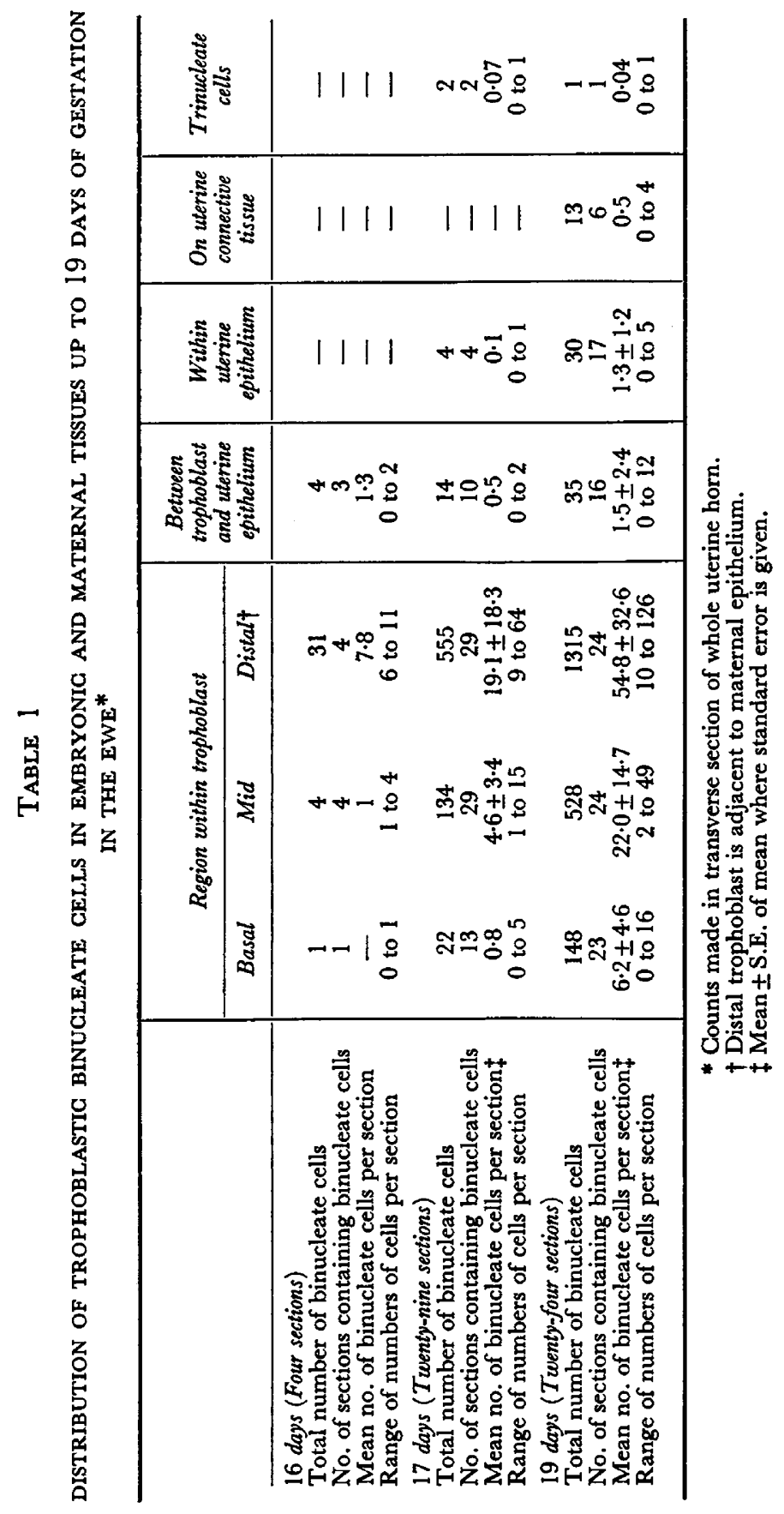


areas by flattened multinucleate symplasm, while other areas appeared to have an attenuated cytoplasmic covering (Pl. 3, Fig. 12). This symplasm was normally PAS-positive in appearance, although not as strongly as were the binucleate cells located within the trophoblast. Occasionally in the basal regions of the crypts the symplasm was not flattened, but appeared rather like a plug of multinucleate tissue extending basally into the stroma.

At all stages the chorionic villi contained vascularized mesenchyme and were completely covered by trophoblastic epithelium. During the 5 th and 6 th weeks of development, the binucleate cells were the predominant cell type in the apical regions of the chorionic villi. The basal areas of the caruncular crypts adjacent to them occasionally contained no symplasmic plaques. On these occasions there was usually evidence of nuclear vacuolation and cellbreakdown within the stroma at this position.

It has already been noted that during the 4 th week of gestation, there was a low level of acid phosphatase activity demonstrable in the stromal tissue beneath the modified caruncular epithelium. By the beginning of the 5th week, however, discrete areas of stronger acid phosphatase activity had appeared in the developing caruncular ridges beneath the trophoblast (Pl. 3, Fig. 16). As the villi progressively invaded the endometrial stroma during the 5th and 6th weeks of pregnancy, similar localized areas of high acid phosphatase activity were present in the walls and basal areas of the maternal crypts (Pl. 3, Fig. 17). Strong alkaline phosphatase activity was consistently localized on the apposed surfaces of the chorion and the endometrium, particularly within the basal areas of the endometrial crypts (P1. 3, Figs. 14, 15).

\section{DISCUSSION}

Early implantation of mammalian embryos is essentially a phenomenon involving two epithelial tissues, the embryonic trophoblast and the maternal uterine epithelium. These two epithelial components must retain as closely as possible their normal relationships if implantation is to be successful or if the phenomenon of implantation is to be described in histological and histochemical terms. It is felt that the preparative techniques used in this study have done this, for it has been shown that the first close contact between the trophoblast and uterine epithelium occurs during the 15th day of gestation. Although Green \& Winters (1945) have described blastocyst attachment as occurring about the 10th day of gestation in the ewe, their observation is unlikely to be of physiological significance for no cellular changes within the uterine epithelium were found in the present investigation until the 16th day of gestation.

The observations made suggest that the cellular changes, demonstrable from early in the 3rd week of gestation until mid-way through the 4th week, depending on the area of uterus or caruncle examined, involved either the death or the transformation of the uterine epithelial cells. Changes in endometrial tissues occurred in the epithelium during the early implantation stages and in the connective tissue stroma during its invasion by the chorionic villi at the time of placentomal development.

A number of mechanisms have been implicated in the removal and trans- 
formation of the uterine epithelium during embryo implantation in mammals. Phagocytic activity by trophoblastic binucleate cells has been considered the prime cause by Assheton (1906) and others (see Davies \& Wimsatt, 1966); the release of cytolytic enzymes in the primates by Wislocki, Dempsey \& Fawcett (1948); and both trophoblast phagocytic activity and the release of cytolytic enzymes in rodents by Kirby (1965).

If the trophoblastic binucleate cells are to be implicated as the cause of the removal of the endometrial epithelium, the following phenomena might be anticipated: (1) that their presence would precede that of the first cellular changes in the maternal epithelium; (2) that their frequency, if they were actively phagocytosing cellular material, would be high enough to permit the levels of activity demanded by the rates of cellular death demonstrated here; or (3) that the majority would contain phagocytosed material from the earliest stage of the implantation process. Observations made in this study show that the time of their first appearance, their number, and the cytological appearance of the binucleate cells found in the trophoblast at 16,17 and 19 days of gestation do not support any of the preceding expectations and thus do not support a gross role for these cells during implantation. However, both Björkman (1965) and Davies \& Wimsatt (1966) have described a well-developed endoplasmic reticulum and Golgi zone within the cytoplasm of the trophoblastic binucleate cells. Whether the product synthesized is the precursor of the mucoprotein complex demonstrated between the trophoblast and the maternal epithelium after using the PAS technique, chorionic gonadotrophin (Björkman, 1954; Greenstein, Murray \& Foley, 1958; but compare Davies \& Wimsatt, 1966), a macromolecular complex acting as a biochemical stimulus to epithelial modification, or has some unknown function, cannot be decided at this time.

The initial phase of embryonic attachment and implantation must involve metabolically active apical membranes in the cells of the uterine epithelium and the trophoblast, a requirement satisfied by the strong alkaline phosphatase activity demonstrated in this study. While it is apparent that a number of alkaline phosphatases exist (Pearse, 1960), alkaline phosphatase activity in the brush borders of epithelial cells in the intestine and the kidney proximal convoluted tubule has been taken as evidence of high membrane activity of either an absorptive or a secretory nature (Wislocki \& Dempsey, 1955). In their review of placental histochemistry, Wislocki \& Padykula (1961) have associated alkaline phosphatase activity particularly with the syncytial trophoblast. The results obtained here locate its activity within the superficial membranes of the uterine epithelium and symplasm, and those of the trophoblastic cells in contact with the epithelium. Fahmy (1957) suggested that alkaline phosphatase activity in the sheep placenta may be the site of the conversion of glucose to fructose. The close association between high alkaline phosphatase activity and the presence of neutral muco-polysaccharide reported by Moog \& Wenger (1952) is probably of significance in this study, for the alkaline phosphatase activity localized particularly in the distal surfaces of the trophoblastic cells may be associated with carbohydrate metabolism and the production of the mucoprotein demonstrated by the PAS technique to lie between embryonic and maternal tissues. This PAS-positive material appears to correspond to the 
fibrinoid proposed by Bradbury, Billington \& Kirby (1965) as the barrier to the egress of foetal transplantation antigens.

It has been shown that the cellular transformation of the uterine epithelium was preceded by increasingly strong acid phosphatase activity. This epithelial activity had disappeared in most areas by the 23rd day, by which time the majority of cellular changes within the epithelium were completed. Acid phosphatase activity, linked with its demonstration in particulate sites, has been associated with lysosomal activity in numerous recent histochemical examinations (Novikoff, 1963; Gahan, 1967). The release of lysosomal enzymes results in either the death of the cell or modification of its form (de Duve, 1963; Gahan, 1967). Yet, from examinations of the association between cell death and lysosomal activity, no evidence has been obtained for the release of acid hydrolases in an intact cell; however, within stressed cells such release does occur (Gahan, 1967).

Implantation might well be a stressful phenomenon to the epithelial cells of the uterus. Within these cells, the higher titre of progesterone in the luteal stages of the oestrous cycle is linked in the rat with an increase in the cytolysosome population (Banon, Brandes \& Frost, 1964) and in the ewe with a rise in acid phosphatase (Hafez \& White, 1968). To this, the stress (be it physical or biochemical) of the blastocyst may now be added, resulting in increased cytolysosomal activity which is reflected in increased $\beta$-glucuronidase levels (Prahald, 1962) and the concomitant cellular changes observable during implantation. In this manner, although its control systems cannot be visualized as yet, the ewe's uterine epithelium is changed so that it covers the caruncular stroma with discrete plaques of multinucleate symplasm. The low level of acid phosphatase activity demonstrated at 16 days in the non-pregnant animal is best interpreted as that associated with the terminal stages of the oestrous cycle as demonstrated in the rat by Banon et al. (1964).

In biological situations which preclude continuous observation of cellular or histological phenomena, use is made frequently of a series, in time, of animals to examine such phenomena. From such serial observations, conclusions may be drawn regarding the phenomena within one animal over the period of examination. Such a technique permits the demonstration of a close association between the globular symplasmic plaques of maternal epithelial tissue present during the middle of the 3rd week of pregnancy and the flattened areas of symplasm lining the grooves and ridges of the maternal stroma during early formation of the definitive placentome. It is from such plaques of maternal epithelium that the cryptal syncytium, considered by Björkman (1962, 1965), Ludwig (1962) and Lawn, Chiquoine \& Amoroso (1963) to be of maternal origin because of the arrangement of the villous interdigitations, is derived.

No evidence was obtained in this study to support the proposal that the trophoblastic binucleate cells are major contributors to the formation of the cryptal syncytium (Wimsatt, 1950, 1951; Davies \& Wimsatt, 1966) during the first 6 weeks of pregnancy. The PAS-staining technique is a relatively nonspecific one for polysaccharide complexes (Pearse, 1960) and the presence of PAS-positive material is not sufficient evidence on which to base cellular homologies. 
It appears that the symplasmic plaques migrate down the walls of the cryptal arcades as the trophoblastic invasion occurs, in a fashion characteristic of epithelial movement in wound-healing (Weiss, 1959). In this manner, the maternal lining of the crypts takes on its characteristic form of discontinuous syncytia and occasional single cryptal cells (Björkman, 1965) in close contact with the continuous trophoblastic epithelium, i.e. the ovine placenta during the first 6 weeks of pregnancy is predominantly epitheliochorial. After formalin fixation and paraffin embedding, an unequivocal description of the relationships of foetal and maternal tissues in the basal parts of the early placentomal crypts is not possible. However, if the plug of syncytial tissue, which has many features characteristic of decidual cells (Mossman, 1937; Kellas, 1966) present in this area, is found to be lined by an attenuated epithelium, the placentome will be completely epitheliochorial as was suggested by Jenkinson in 1906 .

\section{ACKNOWLEDGMENTS}

The generosity of members of the New Zealand Romney Breeders' Association in donating the sheep used in this study is gratefully acknowledged, as is financial assistance from Merck, Sharp \& Dohme (N.Z.) Ltd received in the latter stages of the investigation. Miss Alison Richards, Mrs Pauline Bain Wheeler, Miss Donna Clooney and Miss Nancy Bellaney have all given willing technical assistance and Mr G. A. Burns prepared the photographs. I also acknowledge with pleasure the unfailing interest and assistance of Professor D. A. Titchen.

\section{REFERENCES}

Aмoroso, E. C. (1951) The interaction of the trophoblast and endometrium at the time of implantation in the sheep. F. Anat. 85, 428.

Amoroso, E. C. (1952) Placentation. In: Marshall's Physiology of Reproduction, 3rd edn. Ed. A. S. Parkes. Longmans Green, London.

Assheton, R. (1906) The morphology of the ungulate placenta, particularly the development of that organ in the sheep, and notes upon the placenta in the elephant and hyrax. Phil. Trans. R. Soc. B, 198, 143.

Banon, P., Brandes, D. \& Frost, J. K. (1964) Lysosomal enzymes in the rat ovary and endometrium during the estrous cycle. Acta cytol. 8, 416 .

Barka, T. \& ANDERson, P. J. (1962) Histochemical methods for acid phosphatase using hexazonium pararosanilin as coupler. 7 . Histochem. Cytochem. 10, 741.

Björkman, N. (1954) Morphological and histochemical studies on the bovine placenta. Acta anat. Suppl. 22 (ad Vol. XXII).

Björkman, N. (1962) Ultrastructural features of the ovine placentome. 5th Int. Congr. Electron Microsc. Vol. 2.

Björkman, N. (1965) Fine structure of ovine placentome. F. Anat. 99, 283.

BoshIER, D. P. (1968) Histological examination of serosal membranes in studies of early embryonic mortality in the ewe. $\mathcal{7}$. Reprod. Fert. 15, 81.

Bradbury, S., Billington, W. D. \& Kirby, D. R. S. (1965) A histochemical and electron microscopical study of the fibrinoid of the mouse placenta. $\mathcal{F l} R$. microsc. Soc. 84, 199.

Davies, J. \& WimsatT, W. A. (1966) Observations on the fine structure of the sheep placenta. Acta anat. $65,182$.

DE Duve, C. (1963) The lysosome concept. In: Lysosomes, GIBA Foundation Symposium. Eds. A. V. S. de Reuck and M. P. Cameron. Churchill, London.

FaHmy, A. N. (1957) Site and origin of fructose in sheep placenta. Gaz. Egypt. Soc. Gynaec. Obstet. 5, 54.

FAwCETT, D. W., Wislocki, G. B. \& Waldo, C. M. (1947) The development of mouse ova in the anterior chamber of the eye and in the abdominal cavity. Am. F. Anat. 81, 413.

Garan, P. B. (1967) Histochemistry of lysosomes. Int. Reo. Cytol. 21, 1. 
Gomori, G. (1952) Microscopic histochemistry, p. 185. University of Chicago Press.

Green, W. W. \& Winters, L. M. (1945) Prenatal development of the sheep. Bull. Minn. agric. Exp. Stn, 169, 1.

Greenstein, J. S., Murray, R. W. \& Foley, R. C. (1958) Observations on the morphogenesis and histochemistry of the bovine preattachment placenta between 16 and 33 days of gestation. Anat. Rec. 132, 321 .

HAfez, E. S. E. \& Whrte, I. G. (1968) Endometrial and embryonic enzyme activities in relation to implantation in the ewe. $\mathcal{F}$. Reprod. Fert. 16, 59.

Jenkinson, J. W. (1906) Notes on the histology and physiology of the placenta in Ungulata. Proc. zool. Soc. Lond. $1,73$.

Kellas, L. M. (1966) The placenta and foetal membranes of the antelope Ourebia ourebi (Zimmermann). Acta anat. 64, 390.

Kirby, D. R. S. (1965) The invasiveness of the trophoblast. In: The Early Conceptus: Normal and Abnormal. Ed. W. W. Park. University of St. Andrews, Dundee.

Lawn, A. M., Chiquorne, A. D. \& Amoroso, E. C. (1963) The ultrastructure of the placenta of the sheep and of the goat. F. Anat. 97, 306.

Lilure, R. D. (1954) Histopathologic technic and practical histochemistry, p. 32. Blakiston, New York.

Ludwig, K. S. (1962) Zur Feinstruktur der materno-fetalen Verbindung des Schafes (Ovis aries L.). Experientia, 18, 212.

MOOG, F. \& WENGER, E. L. (1952) The occurrence of a neutral mucopolysaccharide at sites of high alkaline phosphatase activity. Am. F. Anat. 90, 339.

Mossman, H. W. (1937) Comparative morphogenesis of the foetal membranes and accessory uterine structures. Contr. Embryol. 26, 129.

Novikopr, A. B. (1963) Lysosomes in the physiology and pathology of cells: contributions of staining methods. In: Lysosomes, CIBA Foundation Symposium. Eds. A. V. S. de Reuck and M. P. Cameron. Churchill, London.

Pearse, A. G. E. (1960) Histochemistry, theoretical and applied, 2nd edn. Churchill, London.

Prahald, K. V. (1962) A study of the rat $\beta$-glucuronidase prior to implantation of the ovum. Acta endocr., Copenh. 39, 407.

RADFORD, H. M., WATSON, R. H. \& WOOD, B. F. (1960) A crayon associated harness for the detection of mating under field conditions. Aust. vet. J. 36, 57.

WEIss, P. (1959) Biological aspects of wound healing. In: Tissue aspects of wound healing. Ed. W. B. Patterson. University of Chicago Press.

Wimsatt, W. A. (1950) New histological observations on the placenta of the sheep. Am. F. Anat. 87, 391.

WimsatT, W. A. (1951) Observations on the morphogenesis, cytochemistry and significance of the binucleate giant cells of the placenta of ruminants. Am. F. Anat. 89, 233.

WisLocki, G. B. \& BeNNeTt, H. S. (1943) The histology and cytology of the human and monkey placenta, with special reference to the trophoblast. Am. F. Anat. 73, 335.

Wislocki, G. B. \& Dempsey, E. W. (1955) Electron microscopy of the human placenta. Anat. Rec. 123, 133.

Wislocki, G. B., Dempsey, E. W. \& Fawcett, D. W. (1948) Some functional activities of the placental trophoblast. Obstetl gynec. Surv. 3, 604.

Wislocki, G. B. \& Padykula, H. A. (1961) Histochemistry and electron microscopy of the placenta. In: Sex and Internal Secretions, Vol. II. Ed. W. C. Young. Williams \& Wilkins, Baltimore.

\section{EXPLANATION OF PLATES}

\section{PLATE 1}

FIG. 1. Transverse section of non-pregnant uterus late in oestrous cycle; caruncular and inter-caruncular areas in upper and lower areas of photograph respectively. Haematoxylin and eosin. $\times 80$.

Fig. 2. Attachment zone of trophoblast to uterine epithelium, 15 days post coitum ( $p c$ ). Haematoxylin and eosin. $\times 500$.

Fig. 3. 16-Day blastocyst lining uterine epithelium. Haematoxylin and eosin. $\times 80$. FIG. 4. 18-Day blastocyst attached to caruncular epithelium before epithelial transformation. Haematoxylin and eosin. $\times 500$. 
PIIE:

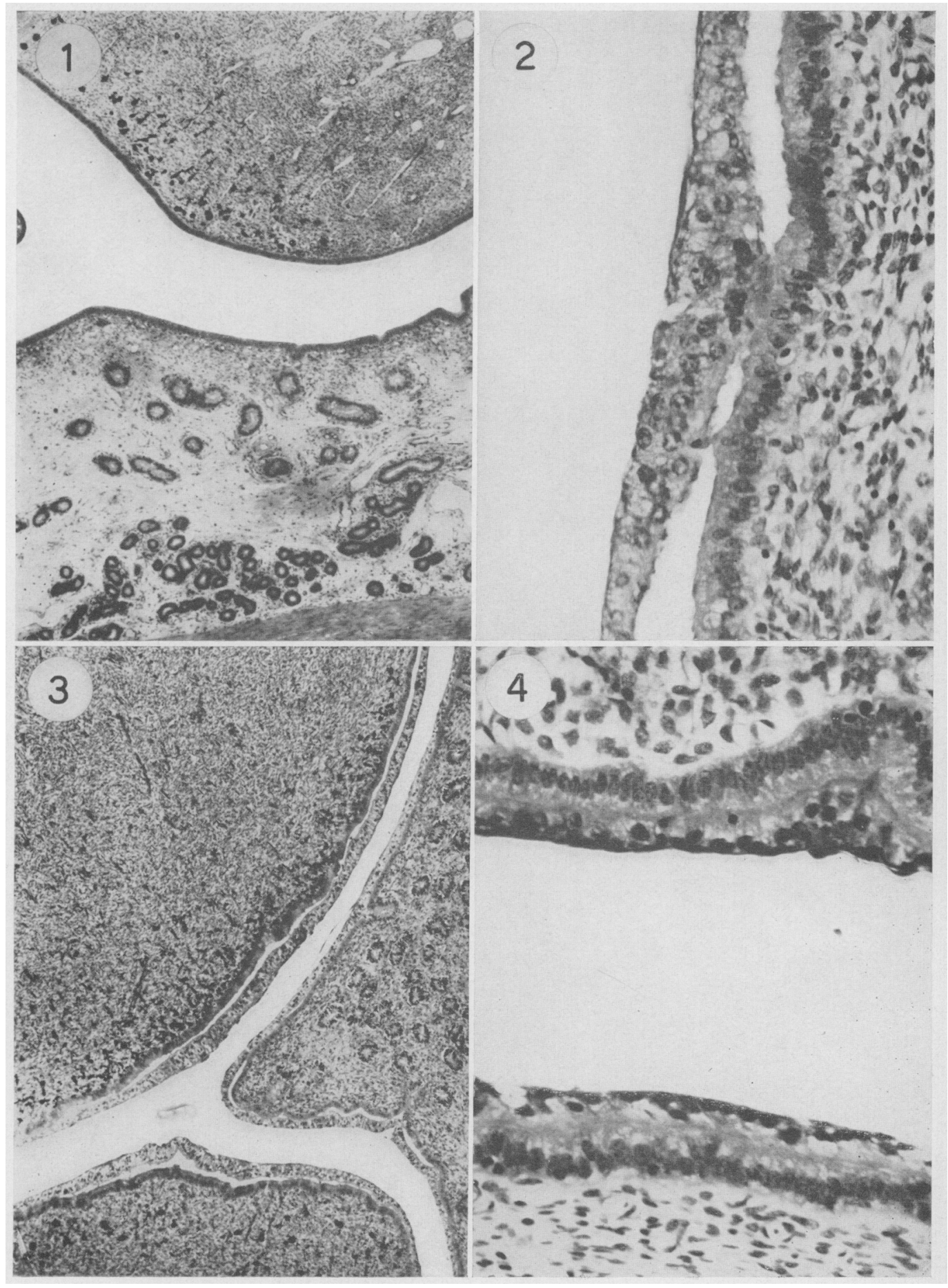

(Facing p.60) 
PI.XTl:2

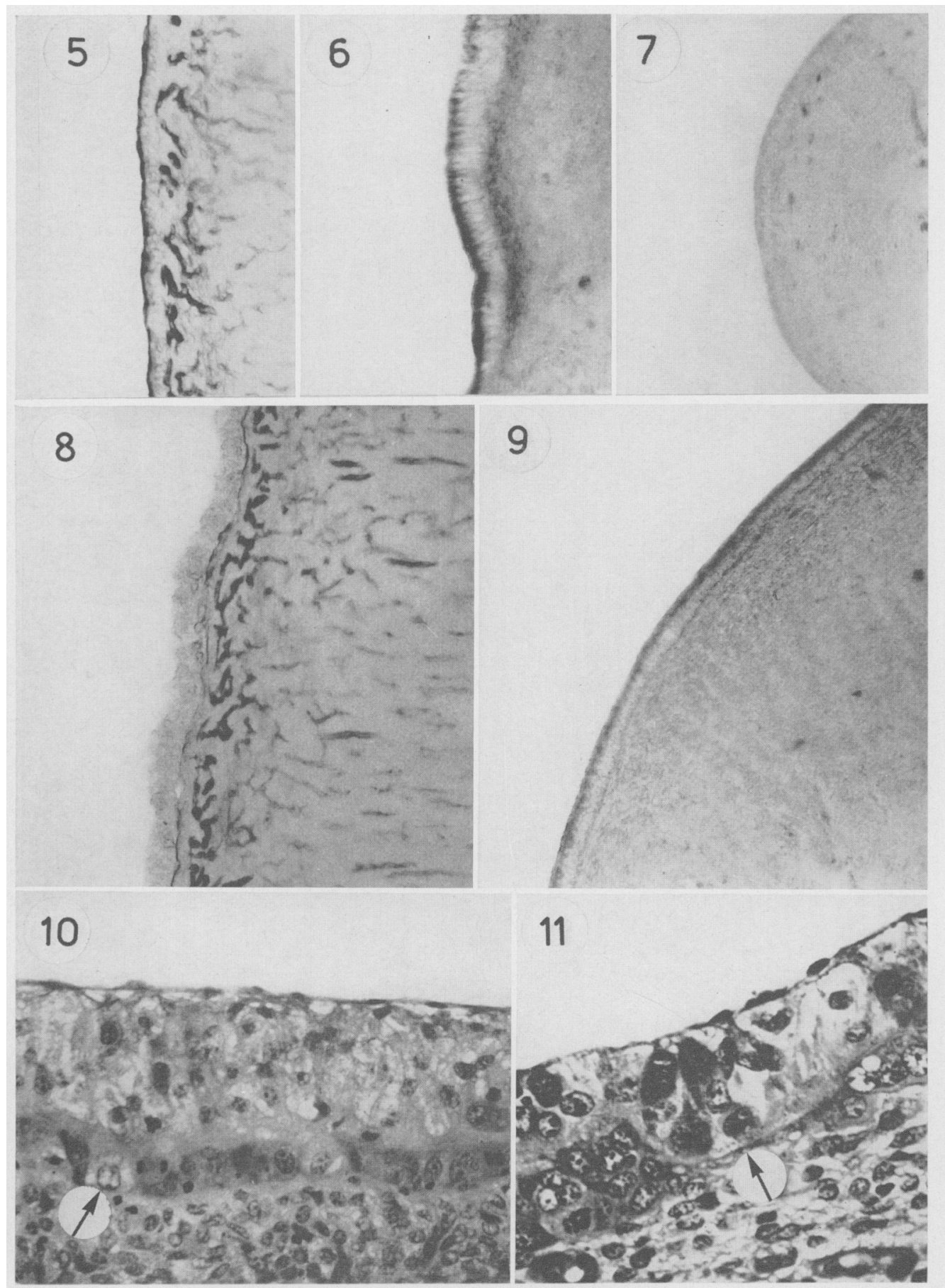


PIATE？

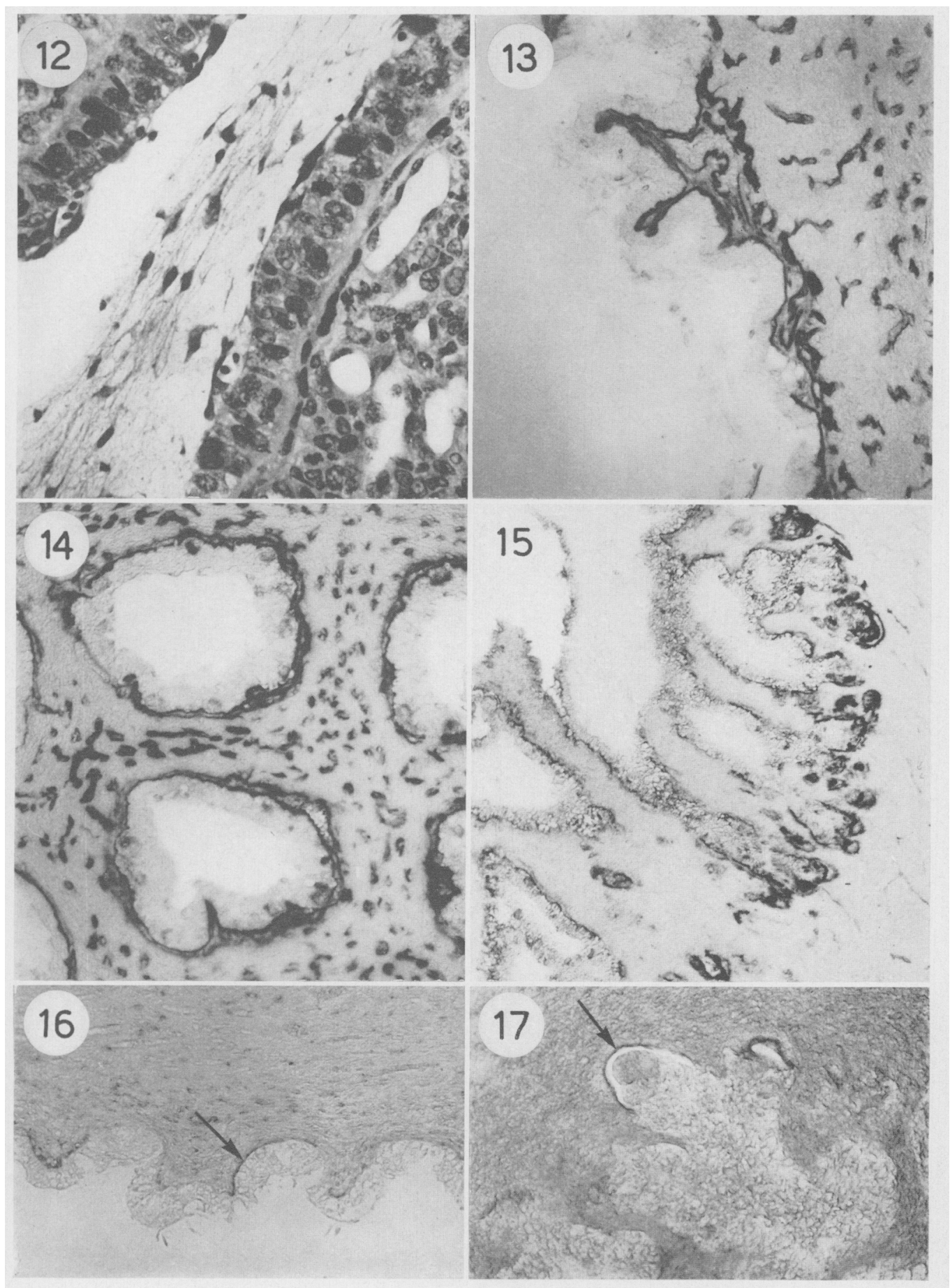


PLATE 2

Fig. 5. Alkaline phosphatase activity in apical cell membranes of uterine epithelium and in sub-epithelial capillaries. 16 days pc. $\times 200$.

FIG. 6. Acid phosphatase activity in apical regions of epithelial cells and in sub-epithelial region. 16 days $p c . \times 200$.

Fig. 7. Lack of acid phosphatase activity in non-pregnant uterus, 16 days after non-fertile mating. $\times 200$.

Fig. 8. Alkaline phosphatase activity in both trophoblast and caruncular epithelium at areas of contact. Note strong activity in sub-epithelial capillaries. 18 days $p c . \times 200$.

Frg. 9. Acid phosphatase activity in apical cytoplasm of caruncular epithelium. 14 days $p c$. $\times 200$.

Fig. 10. Section of implanting trophoblast showing nuclear vacuolation and cellular disintegration within uterine epithelium. Note binucleate giant cells within trophoblast. Haematoxylin and eosin. 16 days $p c . \times 500$.

Fig. 11. Implanting trophoblast of 18 days' gestation showing flattened or globular plaques of symplasm separated by areas of necrotic tissue (arrowed). van Gieson. $\times 800$.

\section{PLATE 3}

FIg. 12. Section of 31-day foetal villus showing central diffuse connective tissue core and well developed trophoblast. The maternal stroma is lined by symplasm of single cell thickness. Note close apposition of maternal symplasm and endothelium of stromal capillary to right of photograph. Haematoxylin and eosin. $\times 800$.

FIG. 13. Alkaline phosphatase activity in adjacent surfaces of trophoblast (left of photograph) and caruncular epithelium at edge of caruncle, 29 days $p c . \times 200$.

FIG. 14. 33-Day placentome with villi and arcades in transverse section showing alkaline phosphatase activity in trophoblast and in uterine symplasm. Note high levels of enzyme activity in maternal capillaries, $\times 200$.

Frg. 15. 38-Day placentome in vertical section showing alkaline phosphatase activity in walls of branching villi and particularly in basal areas of uterine crypts. $\times 80$.

FIG. 16. Section of placentome of 29 days' gestation in which acid phosphatase activity is present in superficial area of uterine stroma (arrowed). $\times 200$.

Fig. 17. Acid phosphatase activity in basal areas of uterine crypts and to a lesser extent in their walls (arrowed). 39 days $p c . \times 200$. 